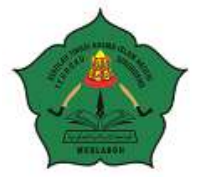

AT-TASYRI' Jurnal Ilmiah Prodi Muamalah

P-ISSN: 2085-2541, E-ISSN: 2715-7865

Volume 13, Nomor 1, Juni 2021

https://ejournal.staindirundeng.ac.id/index.php/Tasyri

\title{
TINJAUAN FIQH EKONOMI TERHADAP PEMBIAYAAN MODAL KERJA MELALUI MURABAHAH PADA PT. BRI SYARIAH
}

\author{
Yoni Hendrawan \\ Institut Agama Islam Negeri Batusangkar \\ yonihendrawan8978@gmail.com \\ Zainuddin \\ Institut Agama Islam Negeri Batusangkar \\ zainuddin@iainbatusangkar.ac.id
}

\begin{abstract}
Abstrak
Artikel ini mengkaji tentang tinjauan fiqh ekonomi terhadap pembiayaan modal kerja (KUR) melalui murabahah pada PT BRISyariah dilihat dari akad dan margin. KUR Mikro Syariah menggunakan akad murabahah pada margin yang menggambarkan besaran keuntungan atau imbalan bagi hasil yang ditentukan pada penyerahan KUR Mikro Syariah. Pemerintah memberikan subsidi margin yakni selisih antara tingkat margin dengan beban margin dari penyalur KUR Mikro Syariah kepada penerima KUR Mikro Syariah. Bagaimana implementasi murabahah pada pembiayaan modal kerja pada PT BRISyariah? dan bagaimana tinjauan Fikih Ekonomi terhadap implementasi murabahah tersebut? Jenis penelitian ini menggunakan studi lapangan dan studi literatur. Metode penelitian ini akan dianalisis secara kualitatif, berdasarkan perspektif Fikih Ekonomi, sebagaimana yang tertuang dalam al-Qur'an, Sunnah dan kitab-kitab fikih dan atau fatwa. Hasil penelitian ini menemukan bahwa implementasi murabahah pada pembiayaan modal kerja pada PT BRISyariah dilakukan dengan cara memberikan pembiayaan murabahah (modal kerja) kepada nasabah untuk pembelian bahan bangunan dengan presentase margin yang ditentukan oleh bank syariah. Margin tersebut disubsidi pemerintah berdasarkan plafon pembiayaan dengan standar margin $6 \%$. Transaksi pembiayaan murabahah hanya berlaku satu kali, walaupun pembelian barang dilakukan berulang-ulang. Menurut Fiqh Ekonomi pembiayaan modal kerja (KUR) murabahah pada PT. BRISyariah yang memakai akad murabahah dengan penyediaan modal kerja berupa uang belum tepat. Karena, pemberian modal kerja dalam bentuk uang lebih tepat mengguakan akad mudharabah.
\end{abstract}

Kata Kunci: Fiqh Ekonomi, Modal Kerja, Murabahah.

\begin{abstract}
Abstrak
This article examines the review of economic fiqh on working capital financing (KUR) through murabahah at PT BRISyariah in terms of contracts and margins. KUR Mikro Syariah uses a murabahah contract on a margin that describes the amount of profit or profit sharing that is determined at the submission of KUR Mikro Syariah. The government provides a margin subsidy, which is the difference between the margin level and the margin burden from KUR Mikro Syariah distributors to KUR Mikro Syariah recipients. How is the implementation of murabahah on working capital financing at PT BRISyariah? and how does the Economic Fiqh review on the implementation of the murabahah? This type of research uses field studies and literature studies. This research method will be analyzed qualitatively, based on the perspective of Economic Jurisprudence, as stated in the Qur'an, Sunnah and fiqh books and / or fatwas. The results of this study found that the implementation of murabahah in working capital financing
\end{abstract}


at PT BRISyariah was carried out by providing murabahah (working capital) financing to customers for purchasing building materials with a margin percentage determined by Islamic banks. This margin is subsidized by the government based on the financing ceiling with a standard margin of $6 \%$. Murabahah financing transactions are only valid once, even though the purchase of goods is made repeatedly. According to the Fiqh of Economics working capital financing (KUR) murabahah at PT. BRISyariah which uses a murabahah contract with the provision of working capital in the form of money is not right. Because, providing working capital in the form of money is more appropriate to use a mudharabah contract.

Keywords: Economic Fiqh, Working Capital, Murabahah.

\section{A. PENDAhULUAN}

Tinjauan Fiqh Ekonomi Tentang Dalam bermuamalah secara Islami diatur beberapa prinsip yang dapat menjadi acuan. Prinsipprinsip tersebut adalah: 1) Tidak mencari rezeki yang haram, baik dari segi zatnya maupun cara mendapatkannya dan tidak pula menggunakannya untuk diharamkan; 2) Tidak menzalimi dan tidak dizalimi; 3) Keadilan pendistribusian kemakmuran; 4) Transaksi dilakukan atas dasar ridha (suka sama suka); 5) Tidak ada unsur riba; 6) Tidak ada unsur maisyir (perjudian); 7) Tidak ada unsur gharar (ketidakjelasan/samar-samar); 8) Tidak ada unsur mudharatdan mafsadat (sesuatu yang dapat mendatangkan kemudaratan dan kerusakan) (Zainuddin, dkk. 2017). Sebagai bagian dari arena bermuamalah prinsip-prinsip ini juga berlaku di perbankan syariah.

Perbankan syariah yang semakin berkembang tidak luput pula pesatnya perkembangan ekonomi Islam. Hal ini berpengaruh pada riba yang dilarang oleh syari'at Islam dengan persepsi masyarakat terhadap bunga (interest) dan capital yang didapatnya telah ditetapkan di muka (predetermined return). Sejak 1950, atas dasar persepsi masyarakat para Cendikiawan Muslim dan teoritisi ekonomi Islam menginginkan terbebasnya dari bunga atau riba (Interest free banking) pada bank (Abdullah Saeed, 2003). Dalam UndangUndang No. 7 Tahun 1992 menjelaskan bahwasanya Lembaga perbankan merupakan salah satu lembaga keuangan di Indonesia. Sehingga PT Bank BRISyariah menjadi pedoman berdirinya bank yang berlandaskan syariah yang mana menghindarkan segala transaksi yang berunsur riba.

PT Bank BRISyariah dalam penghimpun dana dan menyalurkan dana masyarakat melalui kredit usaha mengikuti fungsi lembaga keuangan yang tertera pada Undang-Undang No. 10 Tahun 1998 tentang Perbankan, Undang-Undang No. 23 Tahun 1999 dan Undang-Undang No. 3 Tahun 2004 tentang Bank Indonesia (Bagya Agung Prabowo, 2009). Pada pasal 13 UndangUndang Nomor 10 Tahun 1998 tentang Perbankan menjelaskan prinsip-prinsip syariah. Landasan yuridis formal selanjutnya diatur dalam Undang-Undang Nomor 21 Tahun 2008 tentang Perbankan Syariah tumpuk dasar berdirinya Perbankan dengan sistem syariah Islam.

Pasal 1 butir (25) Undang-Undang No. 21 Tahun 2008 Tentang Perbankan Syariah (sekarang disebut UU Perbankan Syariah) menjelaskan bahwa pembiayaan adalah pengadaan dana atau tuntutan yang dipersamakan atas transaksi bagi hasil dalam bentuk mudharabah dan musyarakah, sewa menyewa dalam bentuk ijarah atau sewa beli dalam bentuk ijarah muntahiya bittamlik, jual beli dalam bentuk piutang murabahah, salam dan istisna, pinjam meminjam dalam bentuk piutang qardh, dan sewa menyewa jasa dalam bentuk ijarah untuk transaksi multijasa. Pasal ini menjadi acuan segala bentuk diterapkan pembiayaan yang ada pada bank syariah.

Jual beli barang atas harga dasar beserta menambahkan keuntungan yang disepakati disebut pembiayaan murabahah. Harga barang yang dibeli dan menetapkan 
keuntungan sebagai tambahannya yang diperoleh penjual harus diberitahukan pada murabahah. Namun pada aplikasi pembiayaan murabahah didapatkan dengan menerapkan modal kerja murabahah. PT Bank BRISyariah menerapkan akad modal kerja murabahah dalam Kredit Usaha Rakyat (KUR) (Lely Shofa Imama. 2014).

Produk murabahah pada bank syariah diatur dengan syarat mekanisme yang berlandaskan prinsip hukum Islam, para pelakunya melihat ada batasan-batasan yang tidak boleh dilanggar yang didalamnya terdapat larangan untuk melakukan transaksi yang mengandung unsur riba, bathil, maysir, dan gharar (Lely Shofa Imama. 2014).

Pada PT BRISyariah terdapat dua macam produk Kredit Usaha Rakyat (KUR), yaitu produk dari pemerintah dan juga produk dari Bank Syariah. Kredit Usaha Rakyat (KUR) adalah pembiayaan modal kerja atau investasi kepada nasabah baik perorangan maupun kelompok usaha yang produktif dan memadai akan tetapi dalam angunan belum memiliki atau belum cukup. KUR Mikro Syariah adalah bagi individu (perorangan) yang menjalankan usaha produktif dan patut dengan peruntukkan pembiayaan pada jumlah pembiayaan maksimal Rp. 25.000.000 (dua puluh lima juta rupiah) per nasabah. KUR Mikro Syariah menggunakan akad murabahah pada margin yang menggambarkan besaran keuntungan atau imbalan bagi hasil yang ditentukan pada penyerahan KUR Mikro Syariah. Pemerintah memberikan subsidi margin yakni selisih antara tingkat margin dengan beban margin dari penyalur KUR Mikro Syariah kepada penerima KUR Mikro Syariah (Sariani Simatupang, 2019).

Permasalahan yang akan diteliti bagaimana implementasi murabahah dalam pembiayaan modal kerja pada pada PT BRIsyariah dan bagaimana pandangan Fikih Ekonomi terhadap implementasi murabahah tersebut.

Modal Kerja (KUR) Melalui Murabahah pada PT BRISyariah

\section{Tinjauan Fiqh Ekonomi Tentang Akad}

Dalam pelaksanaan akad modal kerja murabahah terlebih dahulu diawali dengan akad wakalah, yakni nasabah sebagai wakil (wakalah) pihak bank guna bertransaksi dengan pihak distributor barang. Diakibatkan keterbatasan teknis, pihak bank tidak bisa langsung bertransaksi dengan distributor, atau pihak nasabah bebas memilih barang langsung ke tempat distributor yang posisi akad wakalah sebagai konsekuensi logis dari bank bukanlah distributor pada barang yang dijual. Dengan demikian, suatu hal yang patut dalam melakukan transaksi dengan distributor pihak bank mewakilkan kepada nasabah atau dengan kata lain mengatasnamakan bank (wakalah) (Hasil wawancara dengan Bapak Dedi Saputra selaku Account Officer, tanggal 11 Mei 2020).

Dengan pembiayaan modal kerja murabahah, dengan ilustrasikan, pengusaha bangunan, mengajukan permohonan pembiayaan murabahah (modal kerja) guna pembelian bahan bangunan, senilai Rp. 100 juta. Setelah dievaluasi bank syariah, usahanya layak dan permohonannya disetujui, maka bank syariah akan mengangkat wakil bank syariah untuk membeli dengan dana dan atas namanya kemudian menjual barang tersebut kembali sejumlah Rp 120 juta, dengan jangka waktu 5 bulan dan dibayar lunas pada saat jatuh tempo.

Dianalisis menurut perspektif Fiqh Ekonomi, akad ini telah sesuai dengan Islam, karena memberikan nuansa tolong menolong dengan memberikan modal kerja. Akad ini dibolehkan karena terdapat dalam surat AlBaqarah ayat 275 bahwasanya kehalalan atau kebolehan praktik jual-beli tanpa ada pembatasan dalam pengertian tertentu.

Terlihat jelas dalam Hadis Rasulullah Saw yakni tentang kejadian saat Rasulullah Saw akan melakukan hijrah dan Abu Bakar menyiapkan unta dengan membeli dua unta. Kemudian Rasulullah Saw berkeinginan untuk memilikinya. Kemudian beliau menghubungi Abu Bakar untuk memiliki salah satunya dengan jalan pembelian secara 
tauliyah. Ketika Abu Bakar berkeinginan untuk menawarkan unta dengan gratis, Rasulullah Saw menolaknya. Sebuah model dalam jual-beli yang mempraktikkan penyebutan harga pokok dan laba yang akan diperoleh oleh penjual.

Pembiayaan murabahah yang diterapkan pada pembiayaan modal kerja dengan prinsip jual beli murabahah dengan transaksi hanya berlaku sekali, bukan satu akad dengan pembelian barang berulangulang dalam pengaplikasian pembiayaan untuk modal kerja. Di sini terlihat penamaan modal kerja murabahah menjadi akad murabahah yang sesuai konsep fiqh.

Namun pada hakikatnya pembiayaan modal kerja murabahah dirasa belum tepat untuk dijadikan sebagai pembiayaan, dikarenakan terdapat unsur keuntungan yang sudah pasti diperoleh di dalam pembiayaanya. Akan tetapi pembiayaan mudharabah (bagi hasil) atau musyarakah (penyertaan modal) seharusnya transkasi yang tepat dalam pembiayaan modal kerja. Karena, jika mekanisme murabahah yang dipakai dalam pembiayaan modal kerja berbentuk uang, maka transaksi yang dipakai sama pada bank konvensional yang sering disebut pembiayaan konsumen (consumer finance) yang terdapat unsur bunga. Pinjam meminjam uang dan memakai murabahah dalam transaksi jual beli merupakan transaksi berbentuk pembiayaan konsumen (consumer finance).

\section{Tinjauan Fiqh Ekonomi Tentang Margin}

Perhitungan pembiayaan modal kerja murabahah, sebagaimana yang diilustrasikan dalam permohonan pembiayaan murabahah (modal kerja) digunakan untuk pembelian bahan bangunan. Sehingga PT BRISyariah memiliki patokan margin pembiayaan dalam penetuan margin murabahah. Presentase margin telah ditentukan oleh pihak bank syariah melalui subsidi pemerintah berdasarkan plafon pembiayaan dengan standar margin $6 \%$ di mana jangka waktu pembiayan tidak merubah besaran margin yang diperoleh karena margin telah ditentukan di awal akad. Margin ini dirasakan meringankan oleh pihak nasabah yang melakukan transaksi tersebut.

Dalam fatwa DSN MUI penentuan keuntungan di awal akad pada bank syariah secara prinsip telah sesuai dengan ketentuan syariah. Sebagai penjual harus memberitahu harga produk (harga perolehan) yang dibeli dan menentukan suatu keuntungan (dalam nominal) sebagai tambahannya. Akan tetapi nasabah tidak dapat melakukan negosiasi margin dikarenakan penentuan presentase margin berdasarkan plafon pembiayaan murabahah. Sebab penetapan margin pembiayaan bank syariah langsung dengan nilai margin dari subsidi pemerintah. Hal ini sejalan dengan wawancara yang dilakukan, di mana nasabah tidak tahu menahu terkait adanya tawar menawar yang dapat dilakukan dalam menentukan margin pembiayaan, sehingga mereka langsung menerima pembiayaan dan margin yang ditawarkan bank syariah (Hasil wawancara dengan Bapak Herman selaku Nasabah, tanggal 18 Februari 2020).

Dalam fatwa DSN MUI No. 4 tahun 2000 tentang murabahah bahwa bank syariah secara prinsip penentuan keuntungan di awal akad telah sesuai dengan ketentuan syariah. Sebagai penjual harus memberitahu harga produk (harga perolehan) yang dibeli dan menentukan suatu keuntungan (dalam nominal) sebagai tambahannya. Sedangkan dalam konsep fiqh dan Fatwa DSN MUI 04/DSNMUI/ IV/2000 tentang murabahah, margin (keuntungan) harus ditentukan berdasarkan kesepakatan bersama antara penjual dan pembeli (bank syariah dan nasabah), tidak boleh ditentukan secara sepihak.

Menurut perspektif Fiqh Ekonomi tidak ada larangan untuk mendapatkan keuntungan dan tidak ada pula standar baku untuk menentukan keuntungan. Riwayat Urwah oleh Ahmad dalam musnadnya, bahwasanya tidak adanya unsur kesewenang-wenangan dalam justifikasi haramnya menentukan margin berdasarkan nominal (besaran) keuntungan yang ada. Akhlak Islam dalam menanggapi justifikasi perkara halal-haram 
adalah sangat berhati-hati. Hal ini bersesuaian dengan ushul fiqih: tahrimul halali wa tahlilu harami qarinusy syirki billah (mengharamkan yang halal dan menghalalkan yang haram sama dengan syirik). Termasuk pada margin pembiayaan murabahah tidak ada batasan yang jelas dan mengakar dalam nominal penentuan margin murabahah. Penentuan harga dan margin harus dikembalikan kepada mekanisme pasar yang sehat, kekuatan supply dan demand. Tentu dengan asumsi bahwa pasar dalam kondisi sehat, tidak terjadi perilaku-perilaku zhalim di dalamnya, riba, maysir, gharar, ihtikar, tadlis, bai' najsy, risywah, dan perlilakuperilaku pasar lainnya yang tidak diridhoi Allah SWT. Agar memastikan mekanisme pasar berjalan dengan baik adalah tugas pribadi dan pemerintah dengan melakukan perilaku hisbah (pengawasan/pengendalian). Sehingga penetapan margin oleh pemerintah yang bisa disebut sebagai at-tas' îr al-jabbari. (Muhammad, 2004: 185)

Fikih Ekonomi menegaskan, margin baik secara tunai (cash) ataupun dibayar secara non tunai (credit) tidak menentukan keabsahan transaksi tersebut. Setiap harga yang ditawarkan penjual sudah termasuk margin penjualan. Margin atau keuntungan dalam penjualan merupakan bagian dari ziyadah al-buyu' (tambahan dari penjualan), bukannya ziyadah al-qurudh (tambahan dari pinjaman). Margin sama sekali tidak terkait dengan time value of money, akan tetapi margin dalam konteks ini adalah cost recovery ditambah dengan keuntungan. Sehingga memungkinkan pertukaran manfaat secara adil dan logis (Arie Syantoso. 2017).

Berdasarkan uraian tersebut dapat dipahami bahwa diperbolehkan bagi siapapun untuk mencari keuntungan tanpa ada batasan keuntungan tertentu selama mematuhi hukum-hukum Islam, serta menentukan standar harga sesuai dengan kondisi pasar yang sehat. Namun bila terjadi penyimpangan dan kesewenang-wenangan harga dengan merugikan pihak konsumen, tidak ada halangan bagi penguasa untuk membatasi keuntungan pedagang atau menetapkan harga. Tindakan ini dilakukan harus melalui konsultasi dan musyawarah dengan pihakpihak terkait agar tidak ada yang dilangkahi maupun dirugikan hak-haknya

Penentuan harga jual dan margin murabahah secara sepihak oleh bank dianggap salah satu penyebab penyimpangan secara Fikih Ekonomi. Bank-bank Syariah beranggapan bahwa Al- Qur'an menghalalkan perdagangan, yaitu jual beli dengan laba, dan murabahah termasuk jual beli dengan laba. Mengingat tidak ada pembatasan dalam jumlah tertentu atas keuntungan yang diperoleh dari suatu perdagangan, maka bank-bank syariah secara bebas' menentukan berapapun margin (keuntungan) dari kontrak murabahah.

Berbeda dengan akad mudharabah patokan margin pembiayaan dalam penentuan bagi hasil/nisbah mudharabah dengan mekanisme perhitungan bagi hasil dapat dilakukan dua macam pendekatan pertama pendekatan profit sharing (bagi laba) dan kedua pendekatan revenue sharing (bagi pendapatan) sesuai kesepakatan bersama. Shahibul maal dengan mudharib dalam menentukan nisbah keuntungan berbentuk presentase bukan dengan nilai nominal suatu mata uang (Wika Ramdhani Hafid. 2018). Persentase nisbah diperoleh dari kesepakatan sebelum akad dan setelah melalui proses negosiasi dan tawar menawar. Sehingga nisbah ini yang menjadi indikator pada penentuan pembagian keuntungan untuk para pihak yang berkontrak. Bilamana persentase bagi hasil/nisbah sesuai kesepakatan bersama oleh pihak bank syariah melalui subsidi pemerintah nisbah $6 \%$ maka membuat nasabah ringan dalam melakukan pembiayaan.

\section{B. METODE PENELITIAN}

Jenis penelitian ini adalah field research, yakni penelitian yang semua data didapatkan di lapangan, dan berbentuk deskriptif kualitatif. Dalam penelitian ini yang menjadi objek/lapangan penelitian adalah BRISyariah. Datanya didapatkan melalui indepth interview terhadap pihak BRISyariah, dengan teknik snow ball sampling. Semua data yang didapatkan dalam 
penelitian ini akan dianalisis secara kualitatif, berdasarkan perspektif Fikih Ekonomi, sebagaimana yang tertuang dalam al-Qur'an, Sunnah dan kitab-kitab fikih dan atau fatwa.

\section{HASIL DAN PEMBAHASAN}

\section{Pelaksanaan Pembiayaan Modal Kerja (KUR) Melalui Murabahah PT BRISyariah \\ Murabahah}

Secara bahasa murabahah berasal dari kata "ribh (ar-ribhu) (rabaha), (yurabihu, murabahatan)" yang berarti keuntungan, karena murabahah pada transaksi jual beli harus mengatakan keuntungan yang didapat. Jual beli dengan harga pokok dengan tambahan keuntungan merupakan istilah dari murabahah (Al-Zuhaili, 1984). Secara langsung mengenai murabahah dalam alQuran tidak dijelaskan pada acuan tentang jual beli, perdagangan, laba, dan rugi.

Murabahah adalah kesepakatan antara penjual dan pembeli dengan menjelaskan harga perolehan dan keuntungan (margin) pada transaksi penjualan barang. Karakteristiknya adalah harga produk yang dibeli dan menetapkan suatu tingkat keuntungan sebagai tambahan harus diberitahukan oleh penjual (Tim Pengembangan Perbankan Syari'ah Institut Bankir Indonesia. 2003).

Dalam Fatwa DSN-MUI No. 04/DSNMUI/IV/2000 menyatakan bahwa, murabahah adalah menjual suatu barang dengan menegaskan harga belinya kepada pembeli dan pembeli membayarnya dengan harga yang lebih sebagai laba. Dalam diktum pertama angka empat fatwa tentang murabahah di atas juga ditegaskan bahwa bank membeli barang yang diperlukan nasabah "atas nama bank sendiri", dan pembelian ini harus sah dan bebas riba. Menurut Peraturan Bank Indonesia (PBI) 10/16/PBI/2008 pembiayaan murabahah adalah penyediaan dana atau tagihan yang dipersamakan dengan itu berupa transaksi jual beli dalam bentuk piutang murabahah .

Pembiayaan murabahah yang diterapkan pada pembiayaan modal kerja, pengadaan barang, pembangunan rumah dan lain-lain ini terdapat pada perbankan syariah. Modal Kerja (modal kerja berupa barang) merupakan beberapa contoh dari penerapan pembiayaan murabahah pada perbankan syariah. Prinsip jual beli murabahah dengan transaksi hanya berlaku sekali putus bukan satu akad dengan pembelian barang berulangulang dalam pengaplikasian pembiayaan untuk modal kerja (Wiroso, 2005).

Pada pelaksanaan akad murabahah dengan pengadaan barang dengan tujuan pembiayaan pada bank syariah merupakan prinsip jual beli murabahah contohnya pembelian kendaraan (berupa: sepeda motor, mobil), peralatan rumah tangga (berupa kulkas, mesin cuci), kebutuhan barang untuk investasi (logam mulia) dan sejenisnya. Jika nasabah berkeinginan mempunyai sebuah kendaran, maka nasabah pergi ke bank syariah untuk mengajukan permohonan supaya keinginan mempunyai kendaraan akan dibelikan oleh pihak bank (Wiroso. 2005).

Mekanisme jual beli murabahah dapat juga dilakukan pada renovasi rumah/jual beli rumah dalam bentuk pengadaan material. Seluruh bentuk barang yang dibutuhkan untuk renovasi rumah, seperti bata merah, genteng, cat, kayu dan lain-lain merupakan barang-barang yang diperjualbelikan. Akad tidak dilakukan berulang-ulang dengan transaksi pada pembiayaan berlaku sekali putus (Ah. Azharuddin Lathif. 2012)

Jual beli dengan bentuk murabahah ini terdapat dalam bentuk pesanan, yang diistilahkan oleh Imam Syafi'I sebagai alamir bi al-shira. Ia juga dapat disamakan dengan bay' bi tsaman ajil atau bay' mu'ajal (jual beli yang barangnya diserahkan segera dan pembayaran ditangguhkan atau dilakukan secara berangsur). Oleh sebab itu, murabahah merupakan salah satu bentuk jual beli yang dihalalkan (Iska, 2012).

Dalam pelaksanaan di PT BRISyariah akad modal kerja murabahah terlebih dahulu diawali menggunakan akad wakalah, yakni nasabah sebagai wakil (wakalah) pihak bank guna bertransaksi dengan pihak distributor barang. Diakibatkan keterbatasan teknis, pihak PT BRISyariah tidak bisa langsung bertransaksi dengan distributor, sehingga 
pihak nasabah bebas memilih barang langsung ke tempat distributor yang posisi akad wakalah sebagai konsekuensi logis dari bank bukanlah distributor pada barang yang dijual.

\section{Pembiayaan Modal Kerja Melalui Murabahah}

Pembiayaan modal kerja adalah pembiayaan guna mencukupi kebutuhan pengembangan penghasilan baik secara jumlah penghasilan maupun peningkatan kualitas atau mutu penghasilan. Sedangkan murabahah menurut peraturan Bank Indonesia adalah jual beli barang sebesar harga pokok barang ditambah dengan margin keuntungan yang disepakati.

Dalam pelaksanaan akad modal kerja murabahah di BRISyariah diawali dengan akad wakalah, yakni nasabah sebagai wakil (wakalah) pihak bank guna bertransaksi dengan pihak distributor barang. Disebabkan keterbatasan teknis, pihak bank tidak bisa langsung bertransaksi dengan distributor, atau pihak nasabah bebas memilih barang langsung ke tempat distributor yang posisi akad wakalah sebagai konsekuensi logis dari bank bukanlah distributor pada barang yang dijual. Dengan demikian transaksi distributor dengan nasabah yang mewakili pihak bank atau bertindak atas nama bank (wakalah) (Wawancara Dedi Saputra. Account Officer, tanggal 11 Mei 2020).

Pembiayaan murabahah yang diterapkan pada pembiayaan modal kerja, pengadaan barang, pembangunan rumah dan lain-lain ini terdapat pada perbankan syariah. Modal Kerja (modal kerja berupa barang) merupakan beberapa contoh dari penerapan pembiayaan murabahah pada perbankan syariah. Prinsip jual beli murabahah dengan transaksi hanya berlaku sekali, bukan satu akad dengan pembelian barang berulangulang dalam pengaplikasian pembiayaan untuk modal kerja (Wawancara Dedi Saputra. Account Officer, tanggal 11 Mei 2020).

Perhitungan pembiayaan modal kerja murabahah, sebagaimana peneliti ilustrasikan, Musa pengusaha bangunan, mengajukan permohonan pembiayaan murabahah (modal kerja) guna pembelian bahan bangunan, senilai Rp. 100 juta. Setelah dievaluasi oleh bank syariah, usahanya layak dan permohonannya disetujui, maka bank syariah akan mengangkat Musa sebagai wakil bank syariah untuk membeli dengan dana dan atas namanya kemudian menjual barang tersebut kembali kepada Musa sejumlah Rp 120 juta, dengan jangka waktu 5 bulan dan dibayar lunas pada saat jatuh tempo (Wawancara Dedi Saputra. Account Officer, tanggal 11 Mei 2020).

\section{KESIMPULAN}

Kesimpulan dari penelitian ini menemukan bahwa implementasi murabahah pada pembiayaan modal kerja pada PT Bank BRISyariah dilakukan dengan cara memberikan pembiayaan murabahah (modal kerja) kepada nasabah untuk pembelian bahan bangunan dengan presentase margin yang ditentukan oleh bank syariah. Margin tersebut disubsidi pemerintah berdasarkan plafon pembiayaan dengan standar margin $6 \%$. Transaksi pembiayaan murabahah hanya berlaku satu kali, walaupun pembelian barang dilakukan berulang-ulang. Menurut Fiqh Ekonomi pembiayaan modal kerja (KUR) murabahah pada PT Bank BRISyariah yang memakai akad murabahah dengan penyediaan modal kerja berupa uang belum tepat. Karena, pemberian modal kerja dalam bentuk uang lebih tepat mengguakan akad mudharabah.

\section{DAFTAR PUSTAKA}

Abdullah Saeed. 1996. Islamic Banking and Interest a Study of The Prohibition Of Riba And Contemporery Intrepretation. New York-Koln: E.J Briil Leiden

Ah. Azharuddin Lathif. 2012. Konsep Dan Aplikasi Akad Murâbahah Pada Perbankan Syariah Di Indonesia. Jakarta Selatan: Masyarakat Ekonomi Syariah (MES) Jurnal Ahkam: Vol. XII, No. 2, Juni

Al Zuhaili. 1984. Fiqih Islam Wa Adilatuhu. Lebanon: Dar al Fikri 
Hendrawan \& Zainuddin, Tinjauan Fiqh Ekonomi Terhadap Pembiayaan...

Arie Syantoso. 2017. Interest Dan Margin Perdagangan Dalam Perspektif Ekonomi Syariah. Banjarmasin: AlIqtishadiyah Jurnal Ekonomi Syariah dan Hukum Ekonomi Syariah. Volume: III. No I. Juni 2017

Bagya Agung Prabowo. 2009. Konsep Akad Murabahah Pada Perbankan Syariah (analisa kritis Terhadap Aplikasi Konsep Akad Murabahah di Indonesia dan Malaysia). Yogyakarta: Jurnal Hukum Fakultas Hukum

Buchari Alma. 1994. Ajaran Islam Dalam Bisnis, Edisi Revisi. Bandung: ALFABETA

Fithriyya Mawaddah. 2015. Penerapan Akad Murabahah Dalam Pembiayaan KPR (Studi Komparasi Pada Bank Muamalat Indonesia, dan Bank Syariah Mandiri). Jakarta: Tesis Konsentrasi Ilmu Syariah Program Pasca Sarjana (S2) Institut Ilmu Al-Qur'an (IIQ) Jakarta.

Huda, Nurul, Mohamad Heykal. 2010. Lembaga Keuangan Islam Tinjauan Teoritis dan Praktis. Jakarta: Kencana Prenada Media Group.

Kamal Khir, dkk. 2008. Islamic Banking, a Practical Perspective. Petaling Jaya: Pearson Malaysia Sdn. Bhd.

Lely Shofa Imama. 2014. Konsep Dan Implementasi Murabahah Pada Produk Pembiayaan Bank Syariah. Dosen Jurusan Syariah dan Ekonomi STAIN Pamekasan Jurnal Iqtishadia Vol. 1 No. 2

Lukmanul Hakim, Amelia Anwar. 2007. Pembiayaan Murabahah Pada Perbankan Syariah Dalam Perspektif Hukum di Indonesia. Bandar Lampung: AL-URBAN: Jurnal Ekonomi Syariah dan Filantropi Islam

Mahmudatus Sa'diyah. 2019. Analisis Pengendalian Penyalahgunaan Akad Wakalah Pada Produk Pembiayaan Murabahah di Bmt Se-Kabupaten Jepara. Fakultas Ekonomi dan Bisnis,
UNISNU Jepara: Al-Masraf (Jurnal Lembaga Keuangan dan Perbankan)

Muhammad. 2000. Sistem dan Prosedur Bank Syari'ah. Yogyakarta: UII Press

Muhammad. 2002. Kebijakan Fiskal dan Moneter Dalam Ekonomi Islam, Cet. I. Jakarta: Salemba Empat

Muhammad Syafii Antonio. 2000. Bank Syariah: Suatu Pengenalan Umum. Jakarta: Tazkia Institute

Rahman Ambo Masse. 2010. Konsep Mudharabah Antara Kajian Fiqh dan Penerapan Perbankan. Sekolah Tinggi Agama Islam Negeri (STAIN) Parepare: Jurnal Hukum Diktum

Rini Setiawati, Ratna Widayati. 2019. Penerapan Sistem Pembagian Pendapatan Pada Bank Mudharabah Nagari Syariah Cabang Padang. Akademi Keuangan dan Perbankan Padang

Saeed, Abdullah. 2003. Bank Islam dan Bunga, Studi Kritis dan Interprestasi Kontemporer Tentang Riba dan Bunga Ctk. Pertama. Yogyakarta: Pustaka Pelajar.

Tim Pengembangan Perbankan Syari'ah Institut Bankir Indonesia. 2003. Konsep, Produk dan Implementasi Operasional Bank Syari'ah. Jakarta: Djambatan

Sariani Simatupang. 2019. Implementasi Produk Pembiayaan Kredit Usaha Rakya (KUR) Mikro Ib Pada PT. Bank Rakyat Indonesia Syariah Tbk. Binjai Sudirman. Universitas Islam Negeri Sumatera Utara

Syukri Iska. 2016. Perspektif Fikih Ekonomi Terhadap Pelaksanaan Akad "Utang Piutang” Pada Perbankan Syariah di Sumatera Barat. Batusangkar: Program Pascasarjana STAIN Batusangkar: JURIS

Wiroso. 2005. Jual Beli Murabahah. Yogyakarta: UII Press. 
Hendrawan \& Zainuddin, Tinjauan Fiqh Ekonomi Terhadap Pembiayaan...

Wika Ramdhani Hafid. 2018. Analisis Penerapan Prinsip Profit Sharing Dan Revenue Sharing Program Tabungan Mudharabah Dan Deposito Mudharabah (Studi Pada PT Bank Muamalat Indoensia Kantor Cabang Utama Makassar). Skripsi

Yenti Afrida.2016. Analisis Pembiayaan Murabahah di Perbankan Syariah.
Institut Agama Islam Negeri Imam Bonjol Padang: JEBI (Jurnal Ekonomi dan Bisnis Islam

Zainuddin, Z., Bustamar, B., \& Rozi, S. (2018). Tinjauan Fikih Terhadap Aktivitas Perdagangan di Pasar Bawah Bukittinggi. Al-Risalah, 17(02) 